\title{
Intervention in risky export markets: insurance, strategic action or aid?
}

\author{
Gerda Dewit* \\ Department of Economics, National University of Ireland Maynooth, Maynooth, Co. Kildare, Ireland
}

Received 1 March 1999; received in revised form 1 January 2000; accepted 1 July 2000

\begin{abstract}
Because the use of trade policy is limited by international institutional arrangements, governments pursuing a policy of export promotion may want to use more indirect instruments to achieve their objectives. In that context, this paper focuses on the public provision of export insurance. While the prime objective is insurance against the risk of default faced by firms exporting to risky markets, these insurance programmes are often embedded in more global policy objectives of the exporting country's government. This paper investigates how premium rating of official export insurance is affected by strategic export promotion and the pursuit of other political objectives. (C) 2001 Elsevier Science B.V. All rights reserved.
\end{abstract}

JEL classification: D81; F13

Keywords: Uncertainty; Export credit insurance; Strategic subsidisation; Aid

\section{Introduction}

This paper investigates how public insurance schemes can be used to serve trade-related ${ }^{1}$ or other objectives. A political economy perspective on international trade policy suggests reasons why policy makers may want to use such schemes for goals other than the provision of coverage to risk averse individuals. Firstly, the objective function of policy makers may incorporate a trade-off

\footnotetext{
*Fax: +353-1-708-3934.

E-mail address: Gerda.Dewit@may.ie (G. Dewit).

${ }^{1}$ The reverse question, to what extent trade policy can be used as a substitute for insurance, has also been studied. See Hillman (1989, Chap. 9) and Dixit (1990).
} 
between the traditional welfare losses of intervention and the interests of specific groups in the economy (see, for instance, Hillman, 1989; Long and Vousden, 1991). Secondly, although direct trade intervention is restricted by international regulations, governments can be imaginative in finding ways to use trade policy without incurring sanctions (Rodrik, 1995) or to take advantage of the discretion that some rules allow (Schuknecht, 1991; Finger, 1993). It has also been suggested that the choice of trade policy instruments is governed by the principle of optimal obfuscation, because of political advantage (Magee et al., 1989); that is, indirect methods of intervention may be preferred by governments, to make policy inconspicuous and less noticeable by losers from the policies.

Subsidisation embedded in official export insurance schemes is a less transparent way of promoting exports than direct subsidisation. In this paper, I consider export insurance in the context of trade with use of trade credits. In many OECD-countries, the political risk of default associated with export credits is usually (at least partially) covered by an agency that is owned or supported by the government. Although explicitly prohibited by the WTO, official export insurers tend to operate with sustained budgetary losses. This implies that, overall, officially insured export credits are subsidised (Abraham et al., 1992; Kuhn et al., 1995; Dewit, 1996; Boote and Ross, 1998). In other words, premium rates often systematically fail to reflect accurately the risk in the export contract that is covered. Due to the involvement of the government, premia may be affected by goals other than insurance. This paper examines how strategic motives aimed at profit shifting in oligopolistic markets on the one hand, and politically motivated aid on the other hand, can skew the premium rating in official export insurance schemes.

I first ask to what extent official export credit insurance programmes can be consistent with strategic export promotion, when the only concern of the government is with domestic welfare maximisation. A rationale for strategic export promotion was first set out in Spencer and Brander (1983) and Brander and Spencer (1985). ${ }^{2}$ However, strategic trade policy rules are very sensitive to industry-specific features, implying that governments may not have the information necessary to implement the optimal policy. The proposal has been subjected to various other critiques (for instance, see Dixit, 1984). In particular, Lee (1990) notes that, when foreign ownership of firms is taken into account, the strategic export subsidy is smaller than in the standard (Cournot) case. Feeney and Hillman (2001) go further and argue that diversification in firm shares through international asset markets leaves no welfare basis at all for government intervention through strategic trade policy.

Secondly, I examine how export insurance policies might be influenced by the possibility that the government of the exporting country has a political interest in

\footnotetext{
${ }^{2}$ For a survey of the subsequent literature, see Brander (1995).
} 
the importing economy. Because of such interest, a government may wish to incorporate the provision of "aid" into its export insurance schemes.

While politically motivated aid always mandates a subsidy, optimal strategic intervention can imply a tax or a subsidy. When the scheme involves a subsidy, there will be two (surreptitious) beneficiaries. More specifically, in that case export insurance subsidisation entails benefits to both domestic firms and foreign consumers. Moreover, both these parties benefit irrespective of whether the motive for subsidisation is to capture foreign rents, or to secure political support of domestic firms or even to provide political assistance to the importing country. However, the distribution of the benefits between domestic firms and foreign buyers depends on which of those motives is dominant in the government's objective function underlying the provision of export insurance.

In the model, exporters allow foreign importers deferral of payment. This implies a risk of default. The focus is on the political risk of default, which is the risk of default by the importing country as a whole. Export insurance for this type of risk typically is almost exclusively provided by a government insurance agency, referred to in the model as "the government". In a two-stage game, the government first sets the export insurance premium rate and firms then choose their export action (i.e., quantity or price). Section 2 gives a brief overview of the stylised facts and figures for the provision of official export credit insurance. The premium rate set by a government that cares about domestic profits (net of subsidy costs) only is derived in Section 3. The home exporter is here assumed to be a monopolist in the export market. This allows the determination of optimal premium rating in a benchmark case without strategic interaction between home and foreign firms. Section 4 derives the premium rate when the home firm competes with a foreign rival in the export market. In Section 5, optimal premium rating is discussed when export insurance, in addition to being used for strategic purposes, also incorporates an element of aid. The final section sets out some concluding remarks.

\section{Official export credit insurance: specific features}

Contracts financed by an export credit imply deferral of payment until the credit expires. As a result, exporters are exposed to a risk of foreign default. Private sector insurance against political risk, defined as potential default by the importing country as a whole, is virtually non-existent. Private insurers find the potential losses associated with these risks too high or too difficult to predict. ${ }^{3}$

\footnotetext{
${ }^{3}$ Still, private insurance exists for the commercial risk of default (i.e., potential default by an individual importer) in relatively safe markets, which does not necessarily require a massive capacity for claim reimbursement but may be limited due to problems of asymmetric information.
} 
Hence, in most developed economies, there is an official agency that issues insurance guaranteed by the government. Coverage rates for political risk are constrained and typically vary across agencies between $85 \%$ and $95 \%$. Most agencies never provide full insurance. ${ }^{4}$

The fraction of exports financed by official credits varies widely across countries, even across EU member states (Dewit, 1996, p. 9). For instance, for the period 1988-1992, the average fraction of export credits in total exports was about $5 \%$ in Germany, $12 \%$ in the UK, and more than $20 \%$ in Austria. In the United States, where export insurance is provided by the Eximbank rather than by a separate export insurance agency, insured exports remain limited, accounting only for about $5 \%$ of exports. Some $40 \%$ of total exports were, however, covered by export insurance in Japan.

These officially insured credits are relatively unimportant for trade between OECD-countries, but exports to newly emerging markets and developing regions in general rely heavily on this type of financing. On average, Asian and Eastern European destinations accounted for more than one third of the total contract portfolio of official export insurance credit agencies in the early 1990s, and the share of Asian contracts continued to increase through the 1990s (Boote and Ross, 1998, p. 12). A high fraction of imports is financed by export credits, especially in newly emerging Southeast Asian markets. For instance, in 1995 about 50\%, 30\% and $20 \%$ of imports were financed by export credits in Indonesia, the Philippines and Thailand, respectively. ${ }^{5}$ In developing countries, export credits typically accounted for $37 \%$ of total official debt in 1992, while this figure increased up to $48 \%$ for the 20 main recipients of export credits (Kuhn et al., 1995, p. 7).

A second striking feature of official export insurance schemes involves export subsidisation, reflected in the sustained budgetary losses in the agencies' balance sheets, especially during the second half of the 1980s and the first half of the 1990s.

Table 1 presents figures on premia, recoveries (i.e., defaulted payments that the insurer manages to recuperate at a later date) and claims for the period 1985-1995. Before 1995, the income from official export insurance consisting of premia and recoveries was systematically insufficient to match the reimbursements claimed, covering merely $60 \%$ of claims.

Furthermore, premium rates are set according to export destination. Empirical studies (Abraham et al., 1992; Abraham and Dewit, 2000) show that global export insurance subsidy estimates tend to conceal a pattern of regional concentration towards specific markets. Subsidy rates, measured as the difference between

\footnotetext{
${ }^{4}$ Partial coverage induces exporters to take actions that may facilitate the recovery of defaulted losses, such as the use of escrow accounts. These are accounts held outside the debtor country through which (part of) future export revenues of the debtor are channelled to the creditor (Boote and Ross, 1998, p. 47).

${ }^{5}$ These figures are based on OECD (1995).
} 
Table 1

Premia, recoveries and claims in official export credit insurance for Berne Union members (in billion US dollars unless indicated otherwise) ${ }^{\mathrm{a}}$

Source: Stephens (1999, p. 65).

\begin{tabular}{lclll}
\hline & Premia (1) & Recoveries (2) & Claims (3) & {$[(1)+(2)] /(3)^{\mathrm{b}}$} \\
\hline $1985-1989$ & 9.26 & 17.97 & 47.13 & 0.58 \\
$1990-1994$ & 15.38 & 23.61 & 65.71 & 0.59 \\
$1995-1997$ & 11.10 & 25.90 & 27.62 & 1.34 \\
\hline
\end{tabular}

\footnotetext{
${ }^{\mathrm{a}}$ The Berne Union is the union of credit and investment insurers. Most official export credit insurance agencies of OECD-countries are members.

${ }^{\mathrm{b}}$ Premia plus recoveries as a fraction of claims.
}

claims and premia as a percentage of insured contracts, ranged on average between $2 \%$ and $12 \%$ during the period 1988-1992. However, for export contracts to particular developing countries, especially if they are former colonies, subsidy rates were well beyond the agency's average. For instance, the subsidy rate for export contracts insured against political risk by the Belgian state amounted to $17 \%$ for exports to Africa and Asia during the period 1984-1993. Those contracts accounted for $63 \%$ of the contracts underwritten by the government (Abraham and Dewit, 2000, Table 1, p. 9). These observations lead to a suggestion that aid considerations rooted in political ties with the recipient country may underlie the regional concentration of subsidies.

While premium rates differ according to the export destination, different industries exporting to the same region cannot be legally charged different premium rates. This does, however, not preclude governments from targeting specific industries via export insurance. The share of exports to specific destinations in total industry exports typically differs between industries. Thus, by subsidising specific regional export insurance schemes, the government favours domestic industries that export more to those subsidised export markets relative to other sectors. ${ }^{6}$ Hence, even though premium rates are not industry-specific, the differential subsidisation of export insurance by destination may leave considerable scope for industry targeting, albeit in an indirect way.

Although the WTO had prohibited export subsidisation, the rules for export credit insurance subsidisation were strengthened significantly in 1995, when the Agreement on Subsidies and Countervailing Measures (SCM) came into force. ${ }^{7}$ Long-term losses in export credit insurance programmes were banned and WTO

\footnotetext{
${ }^{6}$ This is in line with the findings by Melitz and Messerlin (1987), who showed that interest subsidies in export credits were concentrated in just a few sectors in France and the UK during the early 1980 s.

${ }^{7}$ See Finger and Schuknecht (1999) for more details on the Subsidy Agreement, which was negotiated during the Uruguay Round.
} 
members who suffered adverse effects from this type of subsidisation could use the dispute settlement system. Table 1 clearly reflects that, after 1995, governments were more constrained in their premium rating policy. In 1995, official export insurers almost reached a break-even position, and afterwards there was a slightly positive cash-flow. In addition, negotiations within the OECD led to the adoption of the Knaepen package (June 1997). From 1999 on, the OECD-Arrangement stipulated minimum premium rates for political risk coverage. ${ }^{8}$

\section{The model: export insurance and a monopolist exporter}

The facts set out in the previous section shape the assumptions of the model. The government of the exporting ("home") country provides insurance against potential default on exports to risky destinations. Private market insurance is not available. Being mainly concerned with insurance against political risk, it can reasonably be assumed that the government has the same information about the risk involved in the contracts as the firms applying for insurance. ${ }^{9}$ In addition, since its portfolio of underwritten contracts is much more diversified than that of firms, the government is assumed to be risk neutral. ${ }^{10}$ Because insurance against political risk typically entails less than full coverage, it is assumed throughout the game that the coverage rate (i.e., the fraction of the value of the export contracts covered by insurance) is fixed at a rate below $100 \% .^{11}$ This coverage rate is denoted by $\bar{\gamma}$, with $\bar{\gamma}<1$.

A two-stage game is set up, in which the government has commitment power in its premium subsidy policy, implying that premium rates are set before firms choose their export actions. There is no consumption of the exported product in the home country. It proves helpful to look first at the case of a home firm that has a monopoly in the export market. This provides a useful benchmark, by eliminating strategic reasons for government intervention, which will be the focus of Section 4. Given the constrained coverage rate, $\bar{\gamma}$, the risk neutral government sets the export insurance premium rate, $r$, in the first stage, with $r$ denoting the premium per insured currency unit. The risk averse monopolist insures risky exports and chooses output for the export market in the second stage.

\footnotetext{
${ }^{8}$ Up to 1999 , the OECD only provided an institutional framework (the "OECD-Arrangement") for the interest rates that could be charged for officially provided export loans.

${ }^{9}$ If anything, the government may be better placed to assess the riskiness of export contracts. This is not necessarily the case for insurance against commercial risk of default, where firms may have access to more information about the risk type of the foreign buyer than the government insurer.

${ }^{10}$ This assumption is not crucial but simplifies the analysis. The main point is that the government is less risk averse than the exporters.

${ }^{11}$ As mentioned in Section 2, limited coverage may, via the actions of exporters, help towards the (ex post) recovery of defaulted payments.
} 


\subsection{The export decision of the monopolist}

The game is solved backwards. The export quantity, $x$, is chosen by the risk averse monopolist in the last stage of the game. Demand in the export market is typically negatively sloped. $R(x)$ denotes the firm's export revenue, with $R_{x}$ $\equiv \frac{\partial R(x)}{\partial x}>0$ and $R_{x x} \equiv \frac{\partial R_{x}}{\partial x}<0 .{ }^{12}$ A constant marginal cost of production is denoted by $c$. The default loss associated with political risk is specific to the importing country and is denoted by $\lambda$, a stochastic variable distributed with mean $E \lambda$ and variance $v^{2}$ over the closed interval $[a, b] \subset[0,1]$. If the insured exporting firm faces foreign default at the expiration date of the contract $(\lambda>0)$, it is reimbursed for this loss through the coverage provided by the insurance policy.

It proves convenient to use a mean-variance formulation for the firm's valuation of risky profits $(E V) .{ }^{13}$ The firm's optimisation problem is thus given by

$$
\max _{x} E V=E \Pi-\frac{\beta}{2} \operatorname{var} \Pi
$$

with

$$
\begin{aligned}
& E \Pi=[1-E \lambda+(E \lambda-r) \bar{\gamma}] R(x)-c x \\
& \operatorname{var} \Pi=(1-\bar{\gamma})^{2} R(x)^{2} v^{2}
\end{aligned}
$$

$E \Pi$ and var $\Pi$, respectively, denote the expected value and the variance of profits. $\beta$ is a positive constant, representing the degree of risk aversion.

I focus on the interior solution only. The first order condition of the problem in Eq. (1) with respect to output is given by

$$
\left[1-E \lambda+(E \lambda-r) \bar{\gamma}-\beta(1-\bar{\gamma})^{2} R(x) v^{2}\right] R_{x}-c=0
$$

The terms of the insurance contract $(r, \bar{\gamma})$ are crucial in determining the firm's export volume. More particularly, other things equal, a premium reduction affects output positively. Furthermore, at a premium equal to or below the expected loss (i.e., $r \leq E \lambda)$, output unambiguously increases in the coverage rate $(\mathrm{d} x / \mathrm{d} \bar{\gamma}>0)$. Since the export decision is not separated from the coverage rate, the variance of

\footnotetext{
${ }^{12} R_{x x}<0$ is required for the second order condition.

${ }^{13}$ A similar approach is adopted by Viaene and de Vries (1992), who analyse the effects of exchange rate uncertainty on trade. The use of the mean-variance approach can be motivated in two ways (see Huang and Litzenberger, 1988). For arbitrary distributions of $\lambda$, the approach can be justified by assuming quadratic utility. Alternatively, for arbitrary preferences, a symmetrically truncated normal distribution would have to be imposed on $\lambda$.
} 
the default variable, $v^{2}$, and the firm's degree of risk aversion, $\beta$, affect the firm's output negatively. ${ }^{14}$

\subsection{Optimal premium rating with "pure" official export insurance}

I now turn to the first stage of the game. Here, the government chooses the premium rate. The premium chosen under the objective of "pure" export insurance is non-strategic, and at the same time does not include any elements of aid through exports to the importing country. I henceforth refer to this premium as the "benchmark" rate.

For insurance programmes to be effective, the contract terms must ensure that risk averse exporters always want to be insured. More specifically, the choice of the optimal premium rate is subject to a participation constraint; that is, $r$ should not exceed $\hat{r}$, with $\hat{r}$ denoting the premium rate that makes the exporter indifferent between taking insurance or not $\left(E V(\hat{r}, \bar{\gamma})=E V\left(x^{R}\right)\right)$, with $x^{R}$ denoting the export volume without insurance. Since the exporter is risk averse, $\hat{r}$ entails a tax ex ante $(\hat{r}>E \lambda)$. Here, the risk neutral government has a "traditional" objective function, represented by $E W$ and consisting of expected profits minus expected subsidy costs. This objective function is maximised subject to the participation constraint for the risk averse exporter, or

$$
\begin{aligned}
& \max _{r} E W=E \pi-E S \\
& \text { s.t. } E V(r, \bar{\gamma}) \geq E V(\hat{r}, \bar{\gamma})
\end{aligned}
$$

Deriving the optimal unconstrained premium rate requires $\mathrm{d} E W / \mathrm{d} r=0$. Since $E W_{r} \equiv \partial E W / \partial r=0$, maximising expression (4) implies

$$
\left(E \pi_{x}-E S_{x}\right) \frac{\mathrm{d} x}{\mathrm{~d} r}=0
$$

with $E \pi_{x} \equiv \partial E \pi / \partial x=[1-E \lambda+(E \lambda-r) \bar{\gamma}] R_{x}-c=\beta(1-\bar{\gamma})^{2} R(x) v^{2} R_{x}$ (from the first order condition in Eq. (3)), and $E S_{x} \equiv \partial E S / \partial x=(E \lambda-r) \bar{\gamma} R_{x}$. The "benchmark" premium rate, obtained from Eq. (5), is denoted by $r^{\text {ins }}$ and is given by:

$$
r^{\text {ins }}=E \lambda-\beta \frac{(1-\bar{\gamma})^{2}}{\bar{\gamma}} R(x) v^{2}
$$

Since $r^{\text {ins }}<E \lambda<\hat{r}$, the participation constraint is not binding. Compared to a situation of certainty (with an equivalent fixed loss of $E \lambda$ ), the risk averse

\footnotetext{
${ }^{14}$ A separation theorem between the export decision and the insurance decision applies when the firm itself can choose the coverage rate simultaneously to the export decision and without constraints (see Funatsu, 1986). However, in the actual practice in export insurance against political risk, the government constrains coverage (see the stylised facts mentioned in Section 2).
} 
domestic firm does not export enough due to the partial coverage. To attain the export volume that would prevail under certainty, the premium rate is set below the expected loss. After the derivation of the benchmark premium rate, the next section turns to strategic premium rating.

\section{Strategic premium rating in official export insurance}

One of the goals often described in the mission statements of official export insurance programmes is export promotion. This section determines the scope for strategic subsidisation in export credit insurance.

\subsection{The export decision of the oligopolist}

Again, the second stage of the game is discussed first. Assume the home exporter now competes with a foreign firm exporting to the risky market. Both firms choose an action ( $a$ and $a^{*}$ for the home and the foreign firm, respectively) which refers to output under Cournot competition and to price under Bertrand competition. ${ }^{15}$ The foreign firm's export is denoted by $x^{*}$, while $c^{*}$ and $\beta^{*}$ are positive constants representing its marginal cost of production and degree of risk aversion, respectively. $r^{*}$ and $\bar{\gamma}^{*}$ indicate the premium and coverage rate in the foreign insurance contract. $R\left(a, a^{*}\right)$ and $R^{*}\left(a, a^{*}\right)$, respectively, denote the revenue function for the home and foreign firm, with $R_{a} \equiv \partial R / \partial a, R_{a a} \equiv \partial R_{a} / \partial a$ $<0, \quad R_{a^{*}}^{*} \equiv \mathrm{\partial} R^{*} / \partial a^{*}$ and $R_{a^{*} a^{*}}^{*} \equiv \mathrm{\partial} R_{a^{*}}^{*} / \partial a^{*}<0$. First order conditions for optimal export actions by the home and the foreign firm, respectively, are

$$
\begin{aligned}
E V_{a}= & {\left[1-E \lambda+(E \lambda-r) \bar{\gamma}-\beta(1-\bar{\gamma})^{2} R\left(a, a^{*}\right) v^{2}\right] R_{a}-c x_{a}=0 } \\
E V_{a^{*}}^{*}= & {\left[1-E \lambda+\left(E \lambda-r^{*}\right) \bar{\gamma}^{*}-\beta^{*}\left(1-\bar{\gamma}^{*}\right)^{2} R^{*}\left(a, a^{*}\right) v^{2}\right] R_{a^{*}}^{*} } \\
& -c^{*} x_{a^{*}}^{*}=0
\end{aligned}
$$

with $E V_{a} \equiv \partial E V / \partial a, E V_{a^{*}}^{*} \equiv \partial E V^{*} / \partial a^{*}, x_{a} \equiv \partial x / \partial a, x_{a^{*}}^{*} \equiv \partial x^{*} / \partial a^{*}$. Furthermore, I assume $c=c^{*}, \beta=\beta^{*}, \bar{\gamma}=\bar{\gamma}^{*}$ and $r^{*}=E \lambda$ for convenience. ${ }^{16}$ Under Cournot competition $R_{a}>0, R_{a^{*}}^{*}>0$ and $x_{a}=x_{a^{*}}^{*}=1$. Bertrand competition

\footnotetext{
${ }^{15}$ This generic approach, encompassing quantity and price competition, is suggested by Leahy and Neary (1997).

${ }^{16}$ Retaliation issues are well understood in this type of subsidy games (hence, $r^{*}=E \lambda$ is assumed). While strengthening the case for a multilateral subsidy ban, retaliation does not eliminate the unilateral incentive to subsidise.
} 
implies $R_{a}<0, R_{a^{*}}^{*}<0, x_{a}<0$ and $x_{a^{*}}^{*}<0$. The second order condition for the home firm requires

$$
\begin{aligned}
E V_{a a}= & {\left[1-E \lambda+(E \lambda-r) \bar{\gamma}-\beta(1-\bar{\gamma})^{2} R\left(a, a^{*}\right) v^{2}\right] R_{a a} } \\
& -\beta(1-\bar{\gamma})^{2} R_{a}^{2} v^{2}<0
\end{aligned}
$$

with $E V_{a a} \equiv \partial E V_{a} / \partial_{a}$. The condition in Eq. (8) is satisfied since $R_{a a}<0$ and it follows from expression (7a) that an interior solution requires the term between square brackets to be positive. Similarly, $E V_{a^{*} a^{*}}^{*}<0$ for the foreign firm.

Whether the firms' reaction functions are positively or negatively sloped crucially depends on the signs of the cross partial derivatives of the first order conditions, $E V_{a a^{*}} \equiv \partial E V_{a} / \partial a^{*}$ and $E V_{a^{*} a}^{*} \equiv \partial E V_{a^{*}}^{*} / \partial a$. For the home firm, the cross partial derivative of its first order condition is given by

$$
\begin{aligned}
E V_{a a^{*}}= & {\left[1-E \lambda+(E \lambda-r) \bar{\gamma}-\beta(1-\bar{\gamma})^{2} R\left(a, a^{*}\right) v^{2}\right] R_{a a^{*}} } \\
& -\beta(1-\bar{\gamma})^{2} R_{a} R_{a^{*}} v^{2}
\end{aligned}
$$

Each firm's own action is assumed to have a larger effect (in absolute value) on its marginal valuation of profits than the rival's action, ${ }^{17}$ implying $E V_{a a}<E V_{a a^{*}}$ and $E V_{a^{*} a^{*}}^{*}<E V_{a^{*} a^{*}}^{*}$.

In addition, the requirements for stability of the game have to be met. ${ }^{18}$ In the certainty case, the stability condition is typically given by $-\left(\pi_{a a}+\pi_{a a^{*}}\right)>0$, with $\pi_{a a} \equiv \mathrm{\partial} \pi_{a} / \partial a$ and $\pi_{a a^{*}} \equiv \mathrm{\partial} \pi_{a} / \partial a^{*}$. With uncertainty, the following condition has to hold for stability:

$$
-\left(E V_{a a}+E V_{a a^{*}}\right)>0
$$

This condition is more restrictive than the corresponding stability condition under certainty, $-\left(\pi_{a a}+\pi_{a a^{*}}\right)>0$, since expression (9) suggests that $E V_{a a^{*}}>0$ may prevail even if $\pi_{a a^{*}}<0$.

Finally, Cournot competition where outputs are strategic substitutes under certainty $\left(\pi_{a a^{*}}<0\right)$ is henceforth referred to as "standard" Cournot competition. Analogously, Bertrand competition where prices are strategic complements under certainty $\left(\pi_{a a^{*}}>0\right)$ will be labelled as "standard" Bertrand competition.

Proposition 1. In a duopoly, export actions which are strategic substitutes under certainty $\left(\pi_{a a^{*}}<0\right)$, are strategic complements with uncertainty and partial export insurance $\left(E V_{a a^{*}}>0\right)$ if the coverage rate is sufficiently low, or if the variance of the default rate in the export market and the degree of risk aversion are sufficiently high.

\footnotetext{
${ }^{17}$ This assumption corresponds to the standard assumption in strategic trade models under certainty under which a firm's own action on its marginal profitability dominates the cross effect (for a detailed discussion, see Leahy and Neary (1997, p. 645).

${ }^{18}$ Stability requirements are discussed in Seade (1980).
} 
Proof. In expression (9) the term between squared brackets is positive as is required by the first order condition in Eq. (7a). $R_{a^{*}}<0$ under Cournot behaviour and $R_{a^{*}}>0$ with Bertrand behaviour. Hence, $R_{a} R_{a^{*}}<0$ under both duopoly types. With standard Bertrand competition under certainty, $\pi_{a a^{*}}>0$ (or $R_{a a^{*}}>0$ with constant $c$ ). Hence, from expression (9), $E V_{a a^{*}}>0$ under uncertainty. With standard Cournot competition under certainty, $\pi_{a a^{*}}<0$ (or $R_{a a^{*}}<0$ with constant $c$ ). However, it follows from Eq. (9) that $E V_{a a^{*}}>0$ will prevail under uncertainty if $^{19}$

$$
\frac{[1-E \lambda+(E \lambda-r) \bar{\gamma}] R_{a a^{*}}}{\left(R_{a a^{*}} R\left(a, a^{*}\right)+R_{a} R_{a^{*}}\right)(1-\bar{\gamma})^{2}}<\beta v^{2}
$$

This inequality is more likely to occur if $\beta$ and/or $v^{2}$ are relatively high, and/or $\bar{\gamma}$ is relatively low. Note that, if $E V_{a a^{*}}>0$ under Cournot competition, a sufficient but non-necessary condition for the stability requirement in Eq. (10) not to be violated follows from Eqs. (8) and (9), and is given by

$$
R_{a}+R_{a^{*}}>0
$$

Proposition 1 implies that reaction functions under Cournot competition are positively sloped if $E V_{a a^{*}}>0$ and $E V_{a^{*}{ }_{a}}>0$. This is immediately clear from the total differentiation of the home firm's first order condition, which implies:

$$
\frac{\mathrm{d} a}{\mathrm{~d} a^{*}}=-\frac{E V_{a a^{*}}}{E V_{a a}}>0
$$

Expression (13) indicates that the slope of the home firm's reaction function is positive.

Intuitively, because both marginal expected profit and marginal profit variability of the domestic firm decrease in $a^{*}$ (with $a^{*}=x^{*}$ for Cournot competition), the sign of $E V_{a a^{*}}$ depends on the relative sizes of each of those effects. If the home coverage rate is sufficiently small, or the home firm's degree of risk aversion and the variance of the default rate in the export market are sufficiently high, the effect on marginal profit variability dominates the effect on marginal expected profit and the home firm's reaction function is positively sloped. A reduction in the home firm's marginal profit variability caused by an expansion of the foreign firm's output, induces the home firm to respond by increasing its output too.

\footnotetext{
${ }^{19}$ The inequality in Eq. (11) guarantees an interior solution provided that $c x_{a}<[1-E \lambda+(E \lambda-r) \bar{\gamma}] R_{a}\left[1-\frac{R_{a a^{*}} R\left(a, a^{*}\right)}{R_{a a^{*}} R\left(a, a^{*}\right)+R_{a} R_{a^{*}}}\right]$ and a similar condition for the foreign firm is imposed.
} 


\subsection{Strategic premium rating in official export insurance}

Taking into account that domestic revenues now depend on the foreign rival's action $\left(R\left(a, a^{*}\right)\right)$, the government sets the regional premium rate by maximising expression (4).

Proposition 2. Even when an export subsidy is optimal in the certainty case, strategic export insurance premium rating involves taxing insured exports if the foreign coverage rate is sufficiently low, or if the variance of the default rate in the export market and the degree of risk aversion by the foreign rival are sufficiently high.

Proof. $E W$ in Eq. (4) is totally differentiated and set equal to zero. Since $E W_{r}=0$ and $E W_{r^{*}}=0$, this procedure yields:

$$
\left(E \pi_{a}-E S_{a}\right) \mathrm{d} a+\left(E \pi_{a^{*}}-E S_{a^{*}}\right) \mathrm{d} a^{*}=0
$$

with $E \pi_{a}=\beta(1-\bar{\gamma})^{2} R\left(a, a^{*}\right) v^{2} R_{a}$ (from Eq. (7a)), $E \pi_{a^{*}}=[1-E \lambda+(E \lambda-$ $r) \bar{\gamma}] R_{a^{*}}, E S_{a}=(E \lambda-r) \bar{\gamma} R_{a}$, and $E S_{a^{*}}=(E \lambda-r) \bar{\gamma} R_{a^{*}}$. After rearranging expression (14), the optimal unconstrained premium rate, $r^{\circ}$, is obtained:

$$
r^{\mathrm{o}}=r^{\mathrm{ins}}-[1-E \lambda] \frac{R_{a^{*}}}{\bar{\gamma} R_{a}} \frac{\mathrm{d} a^{*}}{\mathrm{~d} a}
$$

with $r^{\text {ins }}$ denoting the benchmark rate (see Eq. (6)). The strategic premium element is represented by the last term of expression (15), with $\mathrm{d} a^{*} / \mathrm{d} a=$ $-\left(E V_{a^{*} a}^{*} / E V_{a^{*} a^{*}}^{*}\right)$ denoting the slope of the foreign firm's reaction function. Both under Cournot and Bertrand competition, $R_{a^{*}} / R_{a}<0$. Hence, if $\mathrm{d} a^{*} / \mathrm{d} a>0$ under uncertainty, then $r^{0}>r^{\text {ins }}$. From Proposition $1, \mathrm{~d} a^{*} / \mathrm{d} a>0$ may occur under uncertainty even though $\pi_{a^{*} a}^{*}<0$ under certainty, if the foreign firm's coverage rate is sufficiently low, or the variance of the default rate in the export market and the foreign firm's risk aversion are sufficiently high. Note that, if $r^{o}>\hat{r}$, the participation constraint imposes an upper boundary on the strategic tax and then $r=\hat{r}>E \lambda$. Hence, the actually chosen premium rate, $r$, will be equal to $r=\min \left\{r^{\circ}, \hat{r}\right\}>E \lambda$.

There are many caveats associated with the strategic trade proposals. The government not only needs to know the precise market demand conditions and the firms' cost structures, but also requires accurate information on the type of oligopolistic behaviour as well as the number of competitors in the export market. The analysis here shows that the informational requirements for optimal strategic government action via export insurance are magnified. Besides the coverage rate specified in export insurance schemes, the variability of foreign revenues and the firms' attitudes to risk determine whether the optimal strategic premium rate entails a subsidy or a tax. 
Moreover, there are other issues that make the implementation of a strategic trade policy very problematic. There is, for instance, the fundamental problem of retaliation. Furthermore, recent work (Lee, 1990) has stressed the importance of firms' ownership for the optimal strategic trade policy. Indeed, if asset markets have permitted international diversification by a country's residents - or even without complete diversification-there is no gain to domestic residents from rent-shifting as proposed by strategic trade policy (Feeney and Hillman, 2001).

Thus, the targeting of industries via trade policy for strategic reasons provides a rather limited explanation for the prevalence of export insurance subsidies. A more general explanation is provided by the political economy perspective on trade policy, which suggests that governments tend to favour selected industries to maximise political support.

\section{Aid-related premium rating in official export insurance}

Here, another motive for export insurance subsidisation is presented. More specifically, this section discusses premium rating when the government of the home country has a special political interest in assisting the importing country. The resulting premium rate will then have positive welfare effects in that importing country. Providing cheap export insurance benefits consumers in the export market through lower import prices. I label this type of intervention as politically inspired development aid. Obviously, such "aid" only affects foreign consumers insofar as they value the insured products. Effective assistance via this method therefore requires that a large share of the supported country's total imports is purchased from the "donor" country. A straightforward way of modelling this motive is by including the importing country's consumer surplus, generated from buying the exporters' product, into the objective function of the home government.

With the new motive for intervention, the home government's objective function is denoted by $E \tilde{W}$ and given by

$$
\begin{aligned}
& \max _{r} E \tilde{W}=E \pi-E S+\alpha \operatorname{CS}^{\mathrm{f}}\left(a, a^{*}\right) \\
& \text { s.t. } E V(r, \bar{\gamma}) \geq E V(\hat{r}, \bar{\gamma})
\end{aligned}
$$

The last term in Eq. (16) represents the aid motive in the compounded objective function. A non-negative constant, $\alpha$, denotes the weight ${ }^{20}$ of the importing country's consumer surplus, $\operatorname{CS}^{\mathrm{f}}\left(a, a^{*}\right)$.

If the home exporter would hold a monopoly in the export market, the aid-inspired premium would clearly entail a subsidy. The subsidy reduces the

\footnotetext{
${ }^{20}$ Similarly, Long and Vousden (1991) allocate exogenous weights to different interest groups.
} 
export price, which will increase the consumer surplus in the importing country. In oligopolistic export markets, the aid-inspired premium will be determined by the direct effect of the firm's action on foreign consumer surplus and by the (indirect) strategic effect on foreign consumer surplus.

Proposition 3. The inclusion of "aid" in official export insurance schemes leads to a direct premium subsidy; in oligopolistic export markets, this direct premium subsidy is magnified when firms' actions are strategic complements but dampened when firms' actions are strategic substitutes.

Proof. The total differential of $E \tilde{W}$ in Eq. (16) is set equal to zero. With $E \tilde{W}_{r}=E \tilde{W}_{r^{*}}=0$, this yields

$$
\left(E \pi_{a}-E S_{a}+\alpha \mathrm{CS}_{a}^{\mathrm{f}}\right) \mathrm{d} a+\left(E \pi_{a^{*}}-E S_{a^{*}}+\alpha \mathrm{CS}_{a^{*}}^{\mathrm{f}}\right) \mathrm{d} a^{*}=0
$$

with $\mathrm{CS}_{a}^{\mathrm{f}} \equiv \partial \mathrm{CS}^{\mathrm{f}} / \partial a$ and $\mathrm{CS}_{a^{*}}^{\mathrm{f}} \equiv \partial \mathrm{CS}^{\mathrm{f}} / \partial a^{*} . E \pi_{a}, E \pi_{a^{*}}, E S_{a}$, and $E S_{a^{*}}$ are given with expression (14). Hence, expression (18) is obtained ${ }^{21}$

$$
r=r^{\mathrm{ins}}-\phi \frac{\mathrm{d} a^{*}}{\mathrm{~d} a}-\frac{\alpha}{\bar{\gamma} R_{a}}\left(\mathrm{CS}_{a}^{\mathrm{f}}+\mathrm{CS}_{a^{*}}^{\mathrm{f}} \frac{\mathrm{d} a^{*}}{d a}\right)
$$

with $\phi=[1-E \lambda]\left(R_{a^{*}} / \bar{\gamma} R_{a}\right)$. The aid-related premium element is represented by the last term in Eq. (18), which captures how premium rating is affected by a concern for the consumer surplus in the importing country. Under Cournot behaviour, $\mathrm{CS}_{a}^{\mathrm{f}}>0$ and $R_{a}>0$, while $\mathrm{CS}_{a}^{\mathrm{f}}<0$ and $R_{a}<0$ under Bertrand competition. Hence, the direct effect on the premium rate is negative $\left(-\left(\alpha / \bar{\gamma} R_{a}\right) \mathrm{CS}_{a}^{\mathrm{f}}<0\right)$, always operating towards a subsidy. Since $-\left(\alpha / \bar{\gamma} R_{a}\right) \mathrm{CS}_{a^{*}}^{\mathrm{f}}<0$, the strategic component reinforces the direct effect if $\mathrm{d} a^{*} / \mathrm{d} a>0$ and reduces it if $\mathrm{d} a^{*} / \mathrm{d} a<0$.

Since the absolute value of $\mathrm{d} a^{*} / \mathrm{d} a=-\left(E V_{a^{*} a}^{*} / E V_{a^{*} a^{*}}\right)$ is smaller than one, the aid-inspired premium presumptively entails a premium subsidy. ${ }^{22}$

Thus, in the case of strategic complements aid-inspired and strategic intervention operate in opposite directions, implying that subsidisation occurs at the expense of export rents for the home country. ${ }^{23}$ By contrast, when firms' actions

\footnotetext{
${ }^{21}$ Here too, if the expression in Eq. (18) exceeds $\hat{r}, r=\hat{r}$.

${ }^{22}$ This is always true under strategic complementarity and also holds under strategic substitutability with homogeneous goods. However, under Cournot competition with differentiated goods, the direct subsidy may be dominated by the strategic term, advocating a tax in the unlikely case that $C S_{x}^{f}<C S_{x}^{f}$.

${ }^{23}$ This is true unless the subsidies are so high that they would effectively deter foreign rival exporters. The issue of entry deterring subsidisation is well understood. Dixit and Kyle (1985) have extensively analysed this possibility in a model with certainty.
} 
are strategic substitutes, both the objectives of strategic export promotion and "aid" require subsidisation. In addition, from a political economy perspective, government concern for the political support of certain industries may mandate export insurance subsidies. If the government chooses to subsidise export insurance, then, irrespective of the actual motive behind the subsidisation, both domestic exporters and consumers in the export market benefit from the cheap insurance schemes.

However, which of these two distinct groups is targeted specifically and which will hence be the main beneficiary depends very heavily on the dominant motive of the government underlying its policy of subsidisation. One could to a large extent infer which motive is dominant in the subsidisation of a particular region by examining the composition of the government's portfolio of insured contracts. Suppose a large fraction of export insurance contracts to a particular subsidised region are concentrated in a few domestic sectors, or even, in a few domestic firms. Then, the main motive for subsidising that market is either to secure political support from specific domestic firms or to engage in surreptitious rent-capturing against rival foreign exporters to that market. In either case, it is the group of domestic firms that is specifically targeted by the subsidy. Although foreign importers will gain, the extent to which they benefit may be almost negligible, especially if the subsidising country's exports to the market involved are relatively small. By contrast, if a particular export destination accounts for a large share of total contracts insured by the government of the exporting country, the motivation to subsidise insurance for that region is probably "aid". This is especially likely if insurance contracts to that region are not concentrated in a few industries. While importers will then gain substantially in the form of lower prices for a wide range of products, subsidies do not necessarily accrue to a few specific firms, but are more likely to be spread across domestic industries.

Evidently, for some regions, a mixture of these two motives may be the underlying cause for subsidisation, implying that both domestic firms and foreign importers will benefit significantly. In that case, there are clearly dual surreptitiously targeted beneficiaries to the subsidised export insurance scheme.

\section{Conclusion}

In this paper, a model of official export insurance has been presented. The analysis focused on how public insurance schemes might offer scope for governments to engage inconspicuously in strategic export promotion and to further political interests in risky export markets.

It has been shown that governments can target specific industries indirectly, that is, by subsidising exports to specific markets via the instrument of export insurance. Official export insurance programmes may therefore conceal strategic rent capturing in less developed markets. However, the analysis emphasised that 
strategic intervention via export insurance may involve a premium tax, even if a subsidy would be recommended under certainty. In that case, strategic subsidies via export insurance schemes will affect domestic welfare negatively. Strategic intervention via export insurance thus proves even more problematic than direct strategic export promotion. Hence, a political economy perspective based on securing political support from powerful domestic groups, may provide a more plausible explanation for the pattern of industry targeted support via export insurance.

A second motive for intervention via export insurance has been presented. When the government of the exporting country has a special (political) interest in the importing country, "aid" may be incorporated in official export insurance schemes. "Aid"-inspired subsidies mainly benefit foreign buyers. When, in addition, insured contracts to the subsidised region are highly concentrated in very few export sectors, exporting firms in those sectors will also gain significantly.

Regionally differentiated subsidisation of export insurance has two obfuscatory advantages for a government. Firstly, policies that are internationally prohibited can be disguised behind policy instruments that are allowed. Secondly, policies can be surreptitiously targeted towards particular firms, while the government appears to keep to non-discriminatory rules.

I conclude by outlining the limitations of the analysis. Constructing one general model of official export insurance is an impossible task (Stephens, 1999, p. 5). The model presented here is probably most relevant in the European context. Carmichael (1987) and Gruenspecht (1988) have used an alternative model where firms seeking export credit support can commit to their price before the government (in their models the USA's EximBank) sets the terms of the export credit. Although certainly possible in some cases_Carmichael quotes the case of Boeing - there is no reason to believe that firms can credibly commit to a price as a general rule.

The model is particularly relevant for the practice in export insurance during the period before 1995. Since then, the WTO-rules and OECD arrangements regarding premium rating for political risk have been strengthened, and OECD member states committed to minimum premium rates in 1999. Commitment to non-intervention has been discussed in the literature (see, for instance, Hwang and Schulman, 1993). In the context of export insurance, the current willingness of governments to subscribe to such an agreement coincides with the emergence of the private sector in insuring political risk. Private insurers, however, still limit their activities to relatively safe markets, leaving the high-risk segment of this type of insurance to the government.

\section{Acknowledgements}

I am grateful to Filip Abraham and Dermot Leahy for extremely useful suggestions. In addition, I thank Lode Berlage, Paul De Grauwe, Louis Eeckhoudt, 
Patrick Van Cayseele, seminar participants at the University of Glasgow and three anonymous referees for helpful comments. The research work reported in this paper was financially assisted and supported through a Research Fellowship awarded by the ASEAN-EC Management Centre.

\section{References}

Abraham, F., Dewit, G., 2000. Export promotion via official export insurance. Open Economies Review 11, 5-26.

Abraham, F., Couwenberg, I., Dewit, G., 1992. Towards an EC policy on export financing subsidies: lessons from the 1980s and prospects for future reform. The World Economy 15, 389-405.

Boote, A.R., Ross, D.C., 1998. Officially Supported Export Credits: Recent Developments and Prospects. World Economic and Financial Surveys, International Monetary Fund, Washington.

Brander, J.A., 1995. Strategic trade policy. In: Grossman, G., Rogoff, K. (Eds.), Handbook of International Economics, vol. III, North-Holland, Amsterdam, pp. 1395-1455.

Brander, J.A., Spencer, B.J., 1985. Export subsidies and international market share rivalry. Journal of International Economics 18, 83-100.

Carmichael, C., 1987. The control of export credit subsidies and its welfare consequences. Journal of International Economics 23, 1-19.

Dewit, G., 1996. Essays on Export Insurance Subsidization. Katholieke Universiteit Leuven, manuscript.

Dixit, A., 1984. International trade policy for oligopolistic industries. Economic Journal Conference Papers 94, 1-16.

Dixit, A., 1990. Trade policy with imperfect information. In: Jones, R., Krueger, A. (Eds.), The Political Economy of International Trade. Blackwell, Cambridge, pp. 9-24.

Dixit, A., Kyle, A., 1985. The use of protection and subsidies for entry promotion and deterrence. American Economic Review 75, 139-152.

Feeney, J., Hillman, A.L., 2001. Privatization and the political economy of strategic trade policy. International Economic Review, in press.

Finger, M., 1993. Antidumping: How It Works and Who Gets Hurt. University of Michigan Press, Ann Arbor.

Finger, M., Schuknecht, L., 1999. Market access advances and retreats: the Uruguay round and beyond. The World Bank, Policy Research Working Papers, No. 2232.

Funatsu, F., 1986. Export credit insurance. Journal of Risk and Insurance 53, 679-692.

Gruenspecht, H.K., 1988. Export subsidies for differentiated products. Journal of International Economics $24,331-344$.

Hillman, A.L., 1989. The Political Economy of Protection. Harwood Academic Publishers, Chur.

Huang, C.-F., Litzenberger, R., 1988. Foundations for Financial Economics. North Holland, New York.

Hwang, H.-S., Schulman, C.T., 1993. Strategic non-intervention and the choice of trade policy for international oligopoly. Journal of International Economics 34, 73-93.

Kuhn, M., Horvath, B., Jarvis, C., 1995. Officially Supported Export Credits: Recent Developments and Prospects. World Economic and Financial Surveys, International Monetary Fund, Washington.

Leahy, D., Neary, J.P., 1997. Public policy towards R\&D in oligopolistic industries. American Economic Review 87, 642-662.

Lee, S., 1990. International equity markets and trade policy. Journal of International Economics 29, 173-184.

Long, N.V., Vousden, N., 1991. Protectionist responses and declining industries. Journal of International Economics 30, 87-103.

Magee, S., Brock, W., Young, L., 1989. Black Hole Tariffs and Endogenous Policy Theory. Cambridge Univ. Press, Cambridge. 
Melitz, J., Messerlin, P., 1987. Subventions à l'exportation et objectifs macro-économiques: la France et La Grande Bretagne. Revue Française d'Economie 2, 58-167.

OECD, 1995. Geographical Distribution of Financial Flows to Developing Countries. OECD, Paris.

Rodrik, D., 1995. Political economy of trade policy. In: Grossman, G., Rogoff, K. (Eds.), Handbook of International Economics, vol. III, North-Holland, Amsterdam, pp. 1457-1494.

Schuknecht, L., 1991. The political economy of EC protectionism: national protectionism based on Art. 115, Treaty of Rome. Public Choice 72, 37-50.

Seade, J., 1980. The stability of Cournot revisited. Journal of Economic Theory 23, 15-27.

Spencer, B.J., Brander, J.A., 1983. International R\&D rivalry and industrial strategy. Review of Economic Studies 50, 707-722.

Stephens, M., 1999. The Changing Role of Export Credit Agencies. International Monetary Fund, Washington.

Viaene, J.-M., de Vries, C., 1992. International trade and exchange rate volatility. European Economic Review 36, 1311-1321. 